\title{
Ethno-Cultural Diversity: A Challenging Parameter for ASEAN Regional Integration
}

\author{
Thanawat Pimoljinda \\ Graduate School of Public Administration (GSPA), Burapha University, Thailand \\ Email: thanawatp@buu.ac.th
}

\begin{abstract}
It can be assumed that ethno-cultural diversity presents a challenge to achieving a full-fledged regional community. It has a profound influence upon internal political security and stability which provokes a far-reaching effect upon governments' policy orientation, and in part determining whether the process of regional integration turns into a stable progress or slides toward tension and conflict. Even if economic-led approaches are being implemented with the aim of bolstering the integration process, divergent identities based on ethno-cultural diversities are an acute challenge for both governments' strategic-oriented policies and actions. This article thus sheds light on these issues by capturing the case of the Southeast Asian region in the context of the Association of Southeast Asian Nations (ASEAN) Community, and argues that not only do such diversities shape the political practices of member states, but that as a consequence, interrupt the process of economic-led approaches to regional integration.
\end{abstract}

Keywords: Ethno-religious Diversity, Regional Integration, ASEAN Community

\section{Introduction}

In a couple years, the Association of Southeast Asian Nations (ASEAN) will have its commitment tested by the so-called "One Vision, One Identity, One Community” (see ASEAN Secretariat, 2009). Under such a commitment, and being a focal point of many scholars, citizens in a given member state would be recognized as citizens of ASEAN as a whole (Tsuboi, 2004; Pimoljinda, 2010), in the process becoming part of the post-Second World War phenomena where diverse groups of peoples identified themselves as citizens of a single state. However, in terms of demographic conditions, the Southeast Asian region is seen as a community-of-communities where there are many ethnic groups with diverse cultural heritages (Osborne, 2010).

The long-standing heritage of ethnocultural diversities in this case tends to be exposed as a challenge for, or being an impediment to, the progress of ASEAN regional unification and solidity (Narine, 2005; Loffelholz and Arao, 2010), as it has directly affected member states' security policies. At the same time, economic-led approach to regional integration, which has been manipulated in bolstering the process of regional integration, may thus be challenged accordingly by such diversities (see also Brown, 2005). In view of these circumstances, a means of dealing with this diversity of identities can be considered as a crucial and difficult issue comparable to methods for abating the gap in economic development between member states. A remarkable notion involved with this issue is that the closer their economic cooperation is, the more possibility that the diverse identities within and between member states may clash with one another (Beeson, 2002, 2003).

As mentioned, this essay is thus concerned not to focus directly on political or economic obstacles, but ethno-cultural diversity and its influences in shaping governments' motivations and actions in the process of achieving regional integration. Discussions regarding key parameters represented in this article are threefold: politics among the various ethno-cultural diversities, policy orientation within the diverse political orders, and economic policy in a diversified environment of politics.

\section{Politics among Cultural Diversities}

Generally, an analytical issue regarding regional security had been in place long before the creation of the ASEAN regional organization in 1967, namely, political stability and regional order. These are widely recognized as a result of both internal and external ethno-cultural diversities which, in the past and still today, have influenced political climates both within and between member states (Docena, 2006; see also Osborne, 2010). 
It is a fact that the Southeast Asian region is a pluralist society where ethnic groups have always been in conflict over issues such as rights over territories and resources (Snitwongse and Thompson, 2005; Loffelholz and Arao, 2010). In this regard, central to this section is the discussion about the ways those diversities shape political order and consequently compelling governments to respond to the security issue and political environments surrounding them.

As many scholars have argued, the Southeast Asian region is very unique compared with other regions. This is not only a result of its colonial legacy, but also it has been catalyzed by internal disorder posed by an array of historic and emerging risks on ethno-cultural disputes and rivalries. Apart from physical landscapes, it is a community of divergent identities composed of five main religions (Islam, Buddhism, Christianity, Hinduism, and Confucianism) and some animist-influenced practices, as well as hundreds of ethnic groups living within the region (Acharya, 2003; Hirschman and Edwards, 2007; Loffelholz and Arao, 2010). Within the boundary of any given country, ethnic groups of both indigenous and migrant peoples are bonded together by political force even if they are different both by nature and through nurture. The identity of a group has thus inevitably been compromised by that of other groups at the national level in the course of the intercalation of political intervention (Brown, 1994, 5-32).

Within these circumstances, the majority in a given social structure who share the same identity has undoubtedly gained the privilege of political power over minorities. It is in line with what Docena (2006) stated, claiming that "the decision as to which areas to be included in the emerging states often did not have the expressed democratic consent of the people living in them." With this situation in mind, political systems alone, which are widely argued to be a legacy of the colonial period, are not an ultimate explanatory factor for the obstacles toward regional security and stability. Parallel to this is the political power used by governments, which has a spillover effect upon regional political order (Beeson, 2003). As it can be observed, soft authoritarian power has been manipulated in many democratic states as can be seen in the cases of Thailand, Singapore, Malaysia and the Philippines, for instance (see also Docena, 2006; Hirschman and Edwards, 2007). Selfexpression through mass media and some other public channels is quite limited in scope and detail, and is not accepted as open for general debate and criticism.

As discussed previously, the uniqueness of the Southeast Asian region is thus neither a common identity which people in all member states must share together, nor a framework for member states to proceeds their own policies harmoniously. In contradistinction, it is a unique mix of ethno-cultural diversities which is seen as a natural given, and which is bonded together as the very diverse groups of people and member states in a given geographical area. Consciousness of this distinctiveness within this particular circumstance is seemingly at a higher degree than recognition of such diversities in the ways the ASEAN community is promoted. The notion of community as a sense of sharing and belonging are thus promoted only at the government level rather than being aimed at indigenous peoples themselves. With this in mind, a sense of sharing is thus limited in scope to those of the same origin, while a sense of belonging is confined to relations between peoples with a shared origin. These two parameters make a sense of community quite difficult to pursue, and thereby as a consequence affect more or less upon a sense of community at the regional level.

\section{Ethno-Cultural Forces Upon National Policies}

As discussed in the previous section, ethnocultural identity has more or less, and even either directly or indirectly, influenced the political motivations and actions of governments. According to Beeson (2002), disparate ethnic and religious formations are characteristic of Southeast Asia, representing a major initial challenge to national and regional coherence for policy makers and analysts. In response to this, it is generally exposed in the form of public security and foreign policies, and thereby influencing the postures of governments toward the external world. Clarifying this argument, light is shed on the impacts of Southeast Asian states' policies toward ASEAN's regional integration, especially in the light of politics among and between ethno-cultural diversities.

Basically, during the process of regional integration, the policy decision-making of governments becomes prerogative of regional organs, governmental authority shifts toward the new regional decision-making centers, and the state's administration comes under central regional direction (Puchala, 1973). This is similar to the views expressed in Deutsch, et al. (1957 as cited in Jackson and Sorensen, 
1999) according to which a region will share common cultural, economic, linguistic, or political ties. Under these conditions, it requires reciprocal obligations of governments and citizens in each member state to make the process possible. Nevertheless, as all politics are local with a combination of the distinctiveness of group identity, the influence of local claims toward, or against, the norms of social grouping either directly or indirectly affects the security policy decision-making of the governments.

As we may observe, since the decolonization period of the 1950s and 1960s, the problems stemmed from local minorities that were trying either to separate themselves from national control or to annex themselves with other groups whose identity is the same as a unified territory (see also Brown, 2005; Snitwongse and Thompson, 2005). An evident situation is that even though ASEAN leaders signed the Joint Action to Counter Terrorism at the 7th ASEAN Summit held in Brunei in November 2001 (see ASEAN Secretariat, 2001), local separatist movements and some other transnational terrorist groups are still operating in the region (see Tsuboi, 2004; Pimoljinda, 2010).

Meanwhile, in the context of globalization, as national sovereignty has become politically and economically more mediated by the sovereignty of other states, international organizations, and non-state actors, internal political autonomy is vulnerable, and thereby resonates in the government's perception toward such situations. With these dilemmatic situations, contesting social values and norms have thus become prominent matters on the agendas of governments, adding up to political practices which are represented in the form of both public and foreign policies (Brown, 2005). At this point, even if Southeast Asian states agreed to develop the ASEAN regional organization, maintaining state autonomy and national sovereignty still prevails (Tsuboi, 2004; Narine, 2005).

As discussed above, it can be said that strategic-oriented policies, both public and foreign, toward such challenges have gained more attention, even though internal political and economic activities of each member state have been opened to external involvement. At the same time, the evolution of states' politics and policies also seem less supportive of regional integration, whereas regional institutions cannot play a critical role in compromising these issues (see also Friedrichs, 2012). At this point, states' policies are developed for national security and interests rather than interdependence for regional integration as it should be in line with their commitments.

\section{Economic Integration in Diverse Cultural Identities}

It is clear that ASEAN member states have been enhancing economic cooperation since it was assumed as a channel for preventing regional insecurity and instability from intraregional confrontation and conflict. The direction of economic tendencies within or beyond the regional bloc has increasingly become a substantial scheme of Southeast Asian governments. However, the complexities of interdependence, the fashion of liberal economy, and the tendency towards an integrated capitalist system are widely believed to erode national sovereignty and narrow the capability of governments and people to make choices (Narine, 2005; Friedrichs, 2012). Additionally, as it may be observed, in the current state of economic cooperation, maintaining trade and investment links is seemingly more important to developing ASEAN's economies than measures to promote intra-regional ethno-cultural integration (Acharya, 2003).

In this regard, the rise of economic interdependence, where the long-standing diverse ethno-cultural identities pose potential impacts upon national security and stability, could make the context of regional cooperation ambiguous on the one hand, while also being a potential challenge to ASEAN regional integration processes on the other. As discussed earlier, and in line with the arguments of many scholars, the fear of losing national sovereignty and unity as well as internal social inequalities, partially as caused by trans-border economic globalization, is dynamically pressing some Southeast Asian nationalist elites to think of promoting nationalism (Beeson, 2002, 2003; Acharya, 2003; Narine, 2005). This is because the nature of globalization is undermining the coherence, wholeness, and unity of individual societies. It has also bound together both Southeast Asian peoples and states with external peoples and states, opening room for cross-border engagement among civil societies (Snitwongse and Thompson, 2005).

At the same time, in terms of regional economic development, local economies are yielding to macro-economic agglomerations, and in many cases they are taken advantage of by regional economic competition (see also Loffelholz and Arao, 2010). Lending support to this circumstance is the speech given by 
ASEAN Secretary General Dr. Surin Pitsuwan at the "Seminar on Religious Pluralism in ASEAN" on August 24, 2012, where it was stated that:

“...some religious communities will resist some of the changes. The political and economic contexts of each of the member states are not going to be convincing enough for them to believe that growth and development are for them. Look at the southern Philippines, South Thailand or even the Rakhine state in Burma, (they are not) fully committed to growth. They are looking at and hoping for something else. Growth plus, dignity, freedom, space, sense of ownership and sense of belonging..." (Muqbil, 2012).

With these ethno-cultural dynamics in view, Southeast Asian governments, over many years or perhaps even since it was established in 1967, have advocated the socalled "network-style of regional cooperation" and made use of informal relations to pursue what they referred to as an Asian-style of integration or ASEAN Way (Loffelholz and Arao, 2010). It can be said that ASEAN has adopted two principles consisting of unanimous voting and non-interference in internal matters. With these concepts of cooperation, decisions are mostly non-binding in nature, and lack the capacity to enforce their decisions either at the regional or at the national level. Economic cooperation is thus arguably only a political discourse, proceeding to build a secure environment in the region, while the real economy is still competitive in nature.

As discussed above, member states are thus seemingly pressed from above as the process of globalization is creating crossborder activities which they are no longer able to prohibit, while they are also simultaneously pressured from below by a trend toward everstronger identification with the local community where people live their daily lives and at which level they demand socioeconomic development. The course of economic liberalization might be assumed to promote changes in social structures and values that, in turn, encourage democratization and reduce central authority. With the dynamics of these circumstances as well as the political practices mentioned earlier, regional integration would not be likely to come about unless the states and peoples of each state want it.

\section{Concluding Remarks}

It is clear that Southeast Asian countries are somewhat distinct in their origins and unique in nature. Such a situation, which represents a potential challenge to national and regional order, is rarely drawn into discussion at the level of a regional security arena. On the contrary, it has been left behind as ASEAN leaders thought it is a natural characteristic which needs to be passively accepted. Nevertheless, as discussed in this article, if ASEAN leaders are aiming to make economic cooperation take precedence as the means for the creation of the ASEAN Community, issues of domestic stability and security of individual member states should be addressed initially. Importantly, such considerations are unlikely to be limited to the challenges of ethno-cultural diversities. Also involved is a broader range of questions relating to people-to-people relationships within the Southeast Asian region. An explanatory factor supplementary to this is that it not only stems from the fear of losing national control over the realm of jurisdiction, but also that increasing freedom and rights would pave the way for minority groups to strive for universal acceptance as citizens with the right to demand meeting their self-interests.

\section{References}

[1] Acharya, A. Constructing a Security Community in Southeast Asia: ASEAN and the Problem of Regional Order. London: Taylor \& Francis, 2003.

[2] ASEAN Secretariat. ASEAN Declaration on Joint Action to Counter Terrorism. ASEAN Secretariat, 2001.

[3] ASEAN Secretariat. Roadmap for an ASEAN Community 2009-2015. Jakarta, Indonesia: ASEAN Secretariat, 2009.

[4] Beeson, M. Southeast Asia and the Politics of Vulnerability. Third World Quarterly, 2002, 23(3): 549-564.

[5] -----. Sovereignty under Siege: Globalization and the State in Southeast Asia. Third World Quarterly, 2003, 24(2): 357-374.

[6] Brown, D. Contending Nationalisms in Southeast Asia (Working Paper No.117). Australia: Murdoch University, Asia Research Center, 2005.

[7] -----. The State and Ethnic Politics in Southeast Asia. New York: Routledge, 1994. 
[8] Deutsch, K. W., et al. (1957). Political Community and the North Atlantic Area. In Robert Jackson \& Georg Sorensen (1999). Introduction to international relations. Oxford: Oxford University Press.

[9] Docena, H. Raising a Different Flag: Struggle for Self-determination in Southeast Asia. In Focus on the Global South (2006). Revisiting Southeast Asian Regionalism. Bangkok, Thailand.

[10] Friedrichs, J. East Asian Regional Security: What the ASEAN Family Can (Not) Do. Asian Survey, 2012, 52(4): 754-776.

[11] Hirschman, C. and Edwards, J. Social Change in Southeast Asia. In George Ritzer, ed. The Blackwell Encyclopedia of Sociology, 2007, 9: 4374-4380.

[12] Loffelholz, M. and Arao, D. A. The ASEAN Guide: A Journalist's Handbook to Regional Integration in Southeast Asia. Berlin, Germany: International Institute for Journalism, 2010.

[13] Muqbil, I. Sec-Gen Surin: ASEAN Identity, Cultural Integration As Important As Economics to Avoid Conflict (September 5, 2012). Travel Impact Newswire. Retrieved January 26, 2012, from www.travel-impactnewswire.com

[14] Narine, S. State Sovereignty and Regional Institutionalism in the Asia Pacific (Working Paper Series No. 41). The Pacific Review, 2005, 1-31.

[15] Osborne, M. Southeast Asia: An Introductory History (10th ed.). Sydney, Australia: Allen \& Unwin, 2010.

[16] Pimoljinda, T. Ethno-Religious Movements as a Barrier to an ASEAN Community. Global Asia, 2010, 5(1): 90-94.

[17] Puchala, D. J. International Politics Today. New York: DODD, MEAD \& COMPANY, 1973.

[18] Snitwongse, K. and Thompson, W. S. (eds.). Ethnic Conflicts in Southeast Asia. Singapore: the Institute of Southeast Asian Studies, 2005.

[19] Tsuboi, Y. Nationalism and Regionalism in Asia: Asian Nationalism and Regionalism. Japan: Waseda University, School of Political Science an Economic, 2004. 